\title{
GMNC wt Allele
}

National Cancer Institute

\section{Source}

National Cancer Institute. GMNC wt Allele. NCI Thesaurus. Code C126581.

Human GMNC wild-type allele is located in the vicinity of $3 q 28$ and is approximately $49 \mathrm{~kb}$ in length. This allele, which encodes geminin coiled-coil domain-containing protein 1 , plays a role in the positive regulation of DNA replication. 